Available online at GSC Online Press Directory

GSC Biological and Pharmaceutical Sciences

e-ISSN: 2581-3250, CODEN (USA): GBPSC2

Journal homepage: https://www.gsconlinepress.com/journals/gscbps

(REVIEW ARTICLE)

\title{
Insects as producers of antimicrobial polypeptides: A short review
}

\author{
Ahmed MH Ali ${ }^{1,2}$, Abdur Rauf ${ }^{3}$ and Emad M Abdallah ${ }^{1, *}$ \\ ${ }^{1}$ Department of Science Laboratories, College of Science and Arts, Qassim University, Ar Rass, Saudi Arabia. \\ 2 Department of Zoology and Entomology, Faculty of Science, Assiut University, Assiut, Egypt. \\ ${ }^{3}$ Department of Chemistry, University of Swabi, Swabi-Anbar-, 23430 KPK, Pakistan.
}

Publication history: Received on 29 August 2020; revised on 10 September 2020; accepted on 12 September 2020

Article DOI: https://doi.org/10.30574/gscbps.2020.12.3.0281

\begin{abstract}
The human communities all over the globe, are suffering from emerging and growing of a serious public health problem, the antimicrobial-resistant pathogens, which are resistant to almost all antibiotic classes. This happens in parallel with the decreasing investment in antimicrobial research and development by major pharmaceutical companies as an expensive and high-risk investment. In order to eliminate that phenomenon, the richness and diversity of nature must be taken into account as a cheap and reliable source for antimicrobial drugs. The significance of antimicrobial peptides (AMPs) of insects is widely studied. The source and the method of activity on the insect's immune system in the susceptible arrangement of these particles have been depicted from alternate points of view. The current short-review is briefly highlighted in this interesting topic.
\end{abstract}

Keywords: Insects; Polypeptides; Antibacterial; Antifungal; Antimicrobial; Antibiotics

\section{Introduction}

Prokaryotic microorganisms preceded eukaryotic macro-organisms existence by billions of years, so microorganisms are highly adaptive and most successful creatures in nature and survived since life appeared on earth [1]. The historical relationships and ecological dynamics between microorganisms (bacteria, fungi, protests, viruses) and macroorganisms (animals and higher plants) have been arose since the appearance of these macro-organisms on the planet and resulted in diverse symbiotic relationships, such as parasitism, mutualism and commensalism which playing fundamental roles in evolution [2]. Insects are the most successful group of animal taxon, they possess unrevealed success and adaptation in all ecosystems, they are also capable of producing endless antimicrobial molecules against fungal, bacterial and viral invaders [3].

Insects, the most diverse groups of animals on Earth since their initial appearance, insects have occupied almost every environmental niche while in the meantime, symbiotic and/or pathogenic microorganisms have adapted specifically to insects as host systems [4]. The importance of antimicrobial peptides (AMPs) in relation to the survival of invertebrates is well known. The source and the mode of action on the insects' immune system of these molecules have been described from different perspectives. Insects produce their own AMPs as well as obtain these molecules from various sources.

The human struggle against pathogenic microbes began in ancient time where man used drugs, mostly collected from natural products against microorganisms that he could not see, sometimes he succeeded and sometimes failed [5]. In the current era, regardless the success of antibiotics in the beginning of the last century, antimicrobial resistance in now a global problem and there is no end is in sight of this dilemma [6]. The current short review aimed to highlight the

\footnotetext{
${ }^{*}$ Corresponding author: Emad M Abdallah

Department of Science Laboratories, College of Science and Arts, Qassim University, Ar Rass, Saudi Arabia.

Copyright (C) 2020 Author(s) retain the copyright of this article. This article is published under the terms of the Creative Commons Attribution Liscense 4.0.
} 
importance of antimicrobial peptides (AMPs) secreted from some insects as a promising source of antimicrobial agents that may help curb this phenomenon.

\section{The dilemma of antimicrobial drugs}

In medical history, since the 1940s, antibiotics are considered as one of the most powerful and life-saving drugs, used for treatment, control and prevention of infectious diseases which was pervasive in the pre-antibiotic era, such as pneumonia, cholera, typhoid fever, smallpox, diphtheria, tuberculosis, plaque, and syphilis [7]. However, even in the golden era of antibiotics, scientists have warned from antimicrobial resistance due to the ability of microorganisms, particularly bacteria to withstand these antibiotics by means of enzymatic degradation mechanism [8]. It was observed that, the antibiotic discoveries and development efforts were gradually decreases over time (Figure 1) and in the last decade the discoveries decreased to an extraordinary low level [9]. The problem has worsened with the emergence of multi-drug resistant pathogens which are spreading rapidly all over the world. For example, in the UK and USA, it is estimated that more than $60 \%$ of Staphylococcus aureus isolates are now methicillin-resistant (MRSA), in addition emergence of numerous multi-resistant bacteria such as Salmonella spp., Pseudomonas aeruginosa, Acinetobacter baumanii and Mycobacterium tuberculosis [10]. Moreover, massive production of antibiotics and their applications in other industries is another serious problem. Antibiotics are broadly used and abused in agriculture, poultry and livestock farms, they are massively discharged and aggregated in the environment, particularly soil and water and threatening the natural balance and affecting on the physical and chemical properties of the natural ecosystems on Earth [11]. Increasing frequency and severity of antimicrobial resistance are attributed to many reasons, such as the overuse and misuse of antibiotics [12], the various molecular mechanisms by which microorganism develops resistance like interference with cell wall synthesis, inhibition of protein synthesis, interference with nucleic acid synthesis and inhibition of a metabolic pathway [13]. Finally, the global antimicrobial crisis has a huge economic effect and its impact extends to hospital charges, resources used and hospital costs (cost of drugs, tests, operating costs, and other patient care activities) [14].

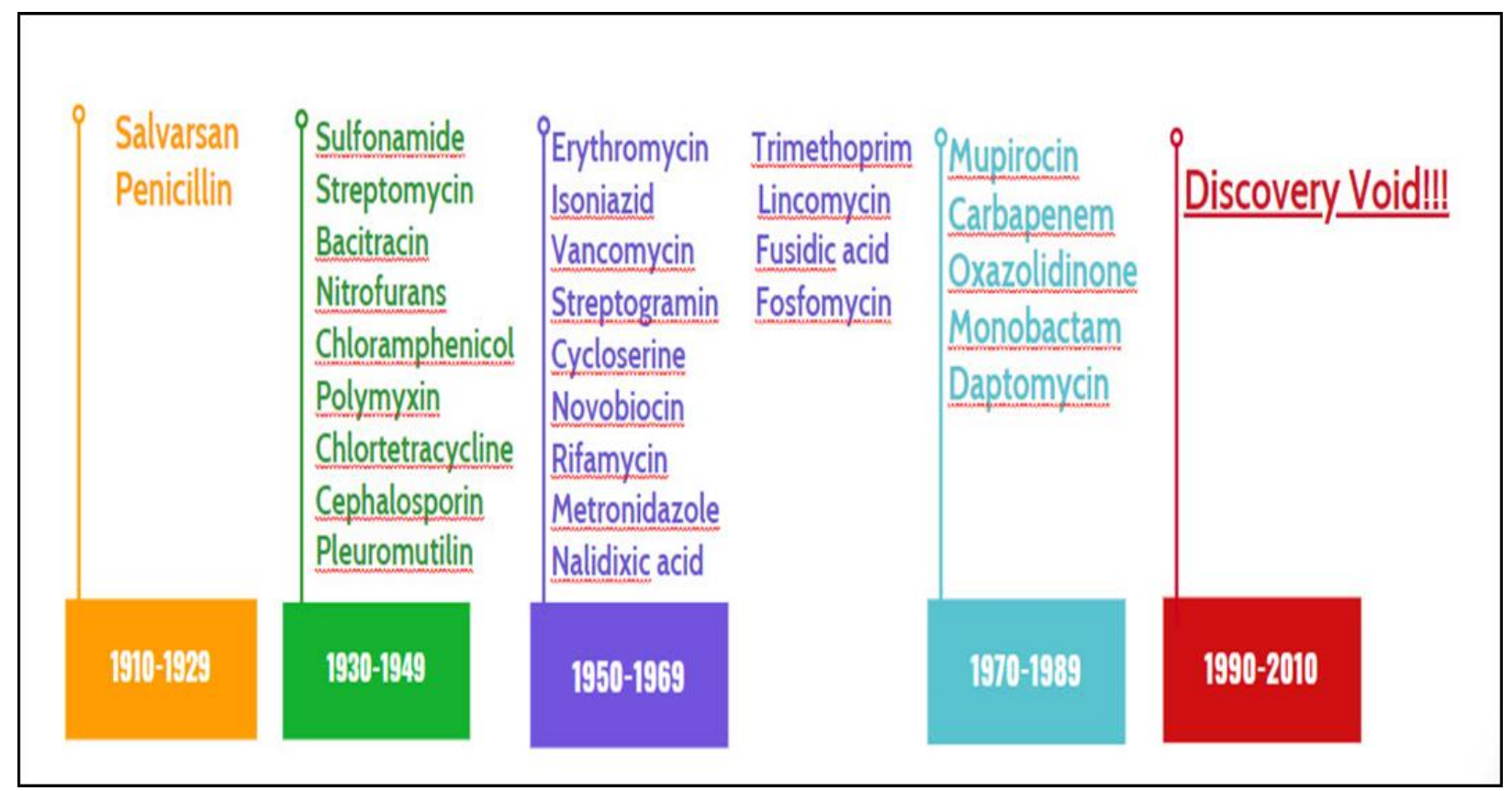

Figure 1 Time-line of the discovery of various antibiotics in clinical use. Adopted from (Silver, 2011).

\section{Insect polypeptides reported as antimicrobial agents}

Insecta is the largest animal class in the kingdom of animalia that using chemicals from numerous varieties of natural products to adapt to the environment and to defend themselves against microbes, predation or infection. Recently, scientific articles have been published about the natural products that produced by insects. An insect innate immune system composed of cellular and humoral mechanisms [15]. The cellular mechanism relies on enzymatic activation that consists of phagocytosis and encapsulation of invading microorganisms by hemolymph. The humoral response is associated with the production of a broad spectrum of molecules, including cationic antibacterial polypeptides (AMPs) that produced in the fat body AMPs, one of the principle components of insect immunity system inside the hemolymph, 
have demonstrated action against microorganisms (parasites, bacteria, viruses).Till now, more than 170 antimicrobial polypeptides have been found in numerous insects. Based on sequence and structural characteristics, these peptides can be probably divided into four expansive classes: (i) cecropins, (ii) cysteine-rich peptides, (iii) pro- line-rich peptides, and (iv) glycine-rich peptides/polypeptides [16,17]. The AMPs exhibited an intriguing option in contrast to commercial antibiotics, which shows low harmfulness to eukaryotic cells, explicitness for bacterial cell membranes, potential antifungal, anti-tumor, and anti-parasitic properties [18]. The first inducible antibacterial action of insects was found in the in the pupae of the giant silk moths Samia cynthia and Hyalophora cecropia [19]. Additionally, the first insect AMP (cecropin) was isolated and characterized from the diapausing pupae of the moth Hyalophora cecropia [20]. Toxins from blister beetles such as pederin and cantharidin have been shown some potential anticancer therapies [18, 21]. AMPs of venom from bees considered as an antimicrobial agent against coronary illness, cancer therapy and skin disorders [22, $23,24]$.

Table 1 Some antimicrobial polypeptides extracted from insects

\begin{tabular}{|l|l|l|l|}
\hline Order & Insect & Antimicrobial peptide & References \\
\hline \multirow{5}{*}{ Lepidoptera } & Spodoptera litura & Cecropin & {$[25]$} \\
& Galleria mellonella & Cecropin & {$[26]$} \\
& Pieris rapae & Hinnavin & {$[27]$} \\
& Bombyx mori & Defensin & {$[28]$} \\
& Mamestra brassicae & Defensin & {$[29]$} \\
\hline \multirow{5}{*}{ Coleoptera } & Acalolepta luxuriosa & Cecropin & {$[30]$} \\
& Oxysternon & Oxysterlin & {$[31]$} \\
& conspicillatum & Coprisin & {$[32]$} \\
& Copris tripartitus & Tenecin & {$[33]$} \\
& Tenebrio molitor & & {$[34]$} \\
\hline \multirow{5}{*}{ Hymenoptera } & Apis mellifera & Royalisin & {$[35]$} \\
& Formica rufa & Defensin & {$[36]$} \\
\hline \multirow{5}{*}{ Isoptera } & Nasonia vitripennis & Navidefensin & {$[37]$} \\
& Pseudacanthotermes & Termicin & \\
\hline
\end{tabular}

\section{Structure-Activity of Antimicrobial polypeptides from insects}

Antimicrobial peptides (AMPs) are multi-functional constituents of the distinctive immunity protection system in eukaryotic as well as prokaryotic organism [38]. AMPs are categorized based on amino acid substitutions into various subgroups. They normally consist of 12 and 50 amino acids and are categorized into subgroups based on their amino acids structure and composition. Among which some of AMPs as short as 7 to 100 amino acids [39]. The hydrophobic portion of antimicrobial peptides (AMPs) takes up more than $50 \%$ residues of amino acids. Antimicrobial peptides (AMPs) secondary structure follows 4 themes including; (a) $\alpha$-helical (b) $\beta$-stranded, (c) $\beta$-hairpin (d) extended conformation [40]. The AMPs have potent antimicrobial effect. Antimicrobial peptides (AMPs) physically interrupt microbial cell membranes and thus kill a wide range of pathogens. Therefore, the membrane of microbe is typically considered the main target of AMPs [41,42]. Furthermore, their promising membrane disruptive action makes theses AMPs ideal candidates for joint therapies with conventional antibiotics [43]. AMPs also help more anti-biotic molecules entering the cytoplasm of microorganism, where they interact with their target. This AMPs kill microbes via a diversity of mechanisms comprising a disruption of membrane, interference with microbe metabolism, as well as targeting the cytoplasmic components [44,45]. The initial contact between AMPs and the target microbe take place through hydrophobic interaction, which mainly dependent on the lipid composition of the microbe membrane [9]. AMPs are capable of interaction with surface of cell membrane and modify the permeability of the membrane [46]. When AMPs interact with cell membrane the made transmembrane potential affects the osmotic pressure equilibrium $[45,46]$. The antimicrobial potential of AMPs is directly correlated due to the interaction between the AMPs and the microbial membranes. The antimicrobial potential of insects is due to a wide range of proteins, peptide molecules which as an excellent defense against pathogen infection [46]. Actually, insects activate the immune system, or target microbe to combat pathogens. 


\section{Conclusion}

Insect peptides have diversity classes of particular AMPs that appear to be promising candidates as antibacterial therapeutics and in different issues of biology, human medicine and the food industries. Insects can possibly be a decent source of AMPs, which might be abused as option in contrast to antibiotic agents in domesticated animal production, including the help of animal development and wellbeing, treatment of diseases and in the conservation of food. Nonetheless, much effort has still to be done to encourage enormous scope creation of insect AMPs and to discover ways for their proficient application in the pharmaceutical industry.

\section{Compliance with ethical standards}

\section{Acknowledgments}

The authors wish to acknowledge the comments of an anonymous reviewer, which have contributed to improve this manuscript.

\section{Disclosure of conflict of interest}

The authors declare that there is no conflict of interest.

\section{References}

[1] Abdallah EM. Plants: An alternative source for antimicrobials. Journal of Applied Pharmaceutical Science. 2011; 1(6): 16-20.

[2] Leung TLF and Poulin R. Parasitism, commensalism, and mutualism: Exploring the many shades of symbioses. Vie Milieu. 2008; 58(2): 107-115.

[3] Narayanan K. Insect defence: its impact on microbial control of insect Pests. Current Science. 2004; 86(6): 800814.

[4] Brachmann AO, Bode HB. Identification and Bioanalysis of Natural Products from Insect Symbionts and Pathogens. In Yellow Biotechnology I; Vilcinskas, A., Ed.; Advances in Biochemical Engineering/Biotechnology. 2013; 135.

[5] Blaser MJ. Who are we? Indigenous microbes and the ecology of human diseases. EMBO Reports. 2006; 7: 956960.

[6] Murray BE. Problems and Dilemmas of Antimicrobial Resistance. Pharmacotherapy. 1992; 12 (6 Pt 2): 86S-93S.

[7] Adedeji WA. The treasure called antibiotics. Annals of Ibadan Postgraduate Medicine. 2016; 14(2): 56-57.

[8] Abraham EP, Chain E. An enzyme from bacteria able to destroy penicillin. Nature. 1940; 146: 837.

[9] Silver LL. Challenges of Antibacterial Discovery. Clinical Microbiology Reviews. 2011; 24(1): 71-109.

[10] Okeke IN. The tragedy of antimicrobial resistance: achieving a recognition of necessity. Current Science. 2009; 97(11): 1564-1572.

[11] Ozumchelouei EJ, Hamidian AH, Yang YZM. (2019). Physicochemical properties of antibiotics: A review with an emphasis on detection in the aquatic environment. Journal of the Water Environment Federation. 2019; 92(2): 177-188.

[12] Tamma PD and Cosgrove SE. Antimicrobial Stewardship. Infectious Disease Clinics. 2011; 25(1): 245 - 260.

[13] Elufisan TO, Oyedara 00, Oyelade B. Updates on microbial resistance to drugs. African Journal of Microbiology Research. 2012; 6(23): 4833-4844.

[14] Eliopoulos GM, Cosgrove SE, Carmeli Y. The Impact of Antimicrobial Resistance on Health and Economic Outcomes, Clinical Infectious Diseases. 2003; 36(11): 1433-1437.

[15] Hoffmann JA, Reichhart J-M, Hetru C. Innate immunity in higher insects. Current Opinion in Immunology. 1996; 8(1): 8-13. 
[16] Hetru C, Hofmann D, Bulet P. Antimicrobial peptides from insects. In: Brey PT, Hultmark D, editors. Molecular mechanisms of immune responses in insects. Chapman \& Hall, UK.

[17] Wu Q, Patoc `ka J, Kuc`a K. Insect antimicrobial peptides, a mini review. Toxins. 2018; $10: 461$.

[18] Hui-Yu Yi, Chowdhury M, Huang Y, Yu XQ. Insect antimicrobial peptides and their applications. Appl Microbiol Biotechnol. 2014; 98: 5807-5822.

[19] Faye I, Pye A, Rasmuson T, Boman HG, Boman IA. Insect immunity: II. Simultaneous induction of antibacterial activity and selective synthesis of some haemolymph proteins in diapausing pupae of Hyalophora cecropia and Samia cynthia. Infect Immun. 1975; 12: 1426-1438.

[20] Steiner H, Hultmark D, Engstro ÈA, Bennich H, Boman HG. Sequence and specificity of two antibacterial proteins involved in insect immunity. Nature. 1981; 292: 246-248.

[21] Ntwasa M, Goto A, Kurata S. Coleopteran antimicrobial peptides: prospects for clinical applications. Int J Microbiol. 2012; Article ID 101989.

[22] Nabiuni M, Safaeinejad Z, Parivar K, Divsalar A, Nazari Z. Antineoplastic effects of honey bee venom. Zahedan J Res Med Sci. 2013; 15: 1-5.

[23] Lee WR, Park KK, Pak SC. The protective effect of bee venom on fibrosis causing inflammatory diseases. Toxins, 7, 4758-4772.

[24] McLoone P, Warnock M, Fyfe L. Honey: a realistic antimicrobial for disorders of the skin. J Microbiol Immunol Infect. 2015; 49: 161-167.

[25] Choi CS, Lee IH, Kim E, Kim SI, Kim HR. Antibacterial properties and partial cDNA sequences of cecropin-like antibacterial peptides from the common cutworm, Spodoptera litura. Comp Biochem Physiol C Toxicol Pharmacol. 2000; 125: 287-297.

[26] Oñate-Garzón J, Manrique-Moreno M, Trier S, Leidy C, Torres R, Patiño E. Antimicrobial activity and interactions of cationic peptides derived from Galleria mellonella cecropin D-like peptide with modelmembranes. J Antibiotch. 2017; 70: 238-245.

[27] Yoe SM, Kang CS, Han SS, Bang IS. Characterization and cDNA cloning of hinnavin II, a cecropin family antibacterial peptide from the cabbage butterfly, Artogeia rapae. Comp Biochem Physiol B Biochem Mol Biol. 2006; 144: 199-205.

[28] Kaneko Y, Tanaka H, Ishibashi J, Iwasaki T, Yamakawa M. Gene expression of a novel defensin antimicrobial peptide in the silkworm, Bombyx mori. Biosci Biotechnol Biochem. 2008; 72: 2353-2361.

[29] Mandrioli M, Bugli S, Saltini S, Genedani S, Ottaviani E. Molecular characterization of a defensin in the IZD-MB0503 cell line derived from immunocytes of the insect Mamestra brassicae (Lepidoptera). Biol Cell. 2003; 95: 5357.

[30] Saito A, Ueda K, Imamura M, Atsumi S, Tabunoki H, Miura N, Watanabe A, Kitami M, Sato R. Purification and cDNA cloning of a cecropin from the longicorn beetle, Acalolepta luxuriosa. Comp Biochem Physiol B Biochem Mol Biol. 2005; 142: 317-323.

[31] Segovia LJT, Ramirez GAT, Arias DCH, Duran JDR, Bedoya JP, Osorio JCC. Identification and characterization of novel cecropins from the Oxysternon conspicillatum neotropic dung beetle. PLoS ONE. 2017; 12 : e0187914.

[32] Hwang JS, Lee J, Kim YJ, Bang HS, Yun EY, Kim SR, Suh HJ, Kang BR, Nam SH, Jeon JP, Kim I, Lee DG. Isolation and characterization of a defensin-like peptide (coprisin) from the dung beetle, Copris tripartitus. Int J Pept. 2009; Article ID 136284.

[33] Moon HJ, Lee SY, Kurata S, Natori S, Lee BL. Purification and molecular cloning of cDNA for an inducible antibacterial protein from larvae of the coleopteran, Tenebrio molitor. J Biochem. 1994; 116: 53-58.

[34] Fujiwara S, Imai J, Fujiwara M, Yaeshima T, Kawashima T, Kobayashi K. A potent antibacterial protein in royal jelly. Purification and determination of the primary structure of royalisin. J Biol Chem. 1990; 265: 11333-11337.

[35] Taguchi S, Bulet P, Hoffmann JA. A novel insect defensin from the ant Formica rufa. Biochimie. 1998; 80: 343346.

[36] Tian C, Gao B, Fang Q, Ye G, Zhu S. Antimicrobial peptide-like genes in Nasonia vitripennis: a genomic perspective. BMC Genomics. 2010; 11: 187. 
[37] Da Silva P, Jouvensal L, Lamberty M, Bulet P, Caille A, Vovelle F. Solution structure of termicin, an antimicrobial peptide from the termite Pseudacanthotermes spiniger. Protein Sci. 2003; 12: 438-446.

[38] Bulet P, Hetru C, Dimarcq JL, Hoffmann D. Abtimicrobial peptides in insects; structure and function. Dev Comp Immun. 1999; 23: 329-344.

[39] Uccelletti D, Zanni E, Marcellini L, Palleschi C, Barra D, Mangoni ML. Anti-Pseudomonas activity of frog skin antimicrobial peptides in a Caenorhabditis elegans infection model: A plausible mode of action in vitro and in vivo. Antimicrob Agents Chemother. 2010; 54: 3853-3860.

[40] Chernysh S, Gordya N, Suborova T. Insect antimicrobial peptide complexes prevent resistance development in bacteria. PLoS ONE. 2015; 10: e0130788.

[41] Shen W, He P, Xiao C, Chen X. From Antimicrobial Peptides to Antimicrobial Poly ( $\alpha$-amino acid) s. Adv Healthc Mater. 2018; 1: 1800354.

[42] Hollmann A, Martinez M, Maturana P, Semorile LC, Maffia PC. Antimicrobial Peptides: Interaction with Model and Biological Membranes and Synergism with Chemical Antibiotics. Front. Chem, 2018; 6: 204.

[43] Tonk M, Vilcinskas A, Rahnamaeian M. Insect antimicrobial peptides: Potential tools for the prevention of skin cancer. Appl Microbiol Biotechnol. 2016; 100: 7397-7405.

[44] Ongey EL, Pflugmacher S, Neubauer P. Bioinspired designs, molecular premise and tools for evaluating the ecological importance of antimicrobial peptides. Pharmaceuticals. 2018; 11: 68.

[45] Wu Q, Patočka J, Kuča K. Insect Antimicrobial Peptides, a Mini Review. Toxins. 2018; 10: 461.

[46] Boman H. Peptide antibiotics and their role in innate immunity. Annual Review in Immunology. 1995 ; 13 : 61-92. 